aeroplanes is $75 \mathrm{kPa}$, so that the arterial oxygen pressure in normal people is about $7 \cdot 3 \mathrm{kPa}$. The condition of patients who already have hypoxia may deteriorate further during a flight if they are not given added oxygen.

For these reasons patients with high spinal injuries are at risk during journeys by aeroplane. We make the following recommendations for such patients:

(1) Lung function should be adequate and stable before transfer.

(2) Humidification of inspired air should be adequate before and during transport, particularly for patients with an endotracheal tube or tracheostomy. If secretions are sticky $2 \mathrm{ml}$ of warm saline can be passed down the endotracheal tube or tracheostomy tube at frequent intervals.

(3) Supplemental oxygen should be available.

(4) Patients should be accompanied by someone trained in manouevres to clear secretions from patients with spinal injuries ${ }^{4}$ and prepared to perform tracheal suction frequently.

(5) Intravenous atropine should be available.
Tracheal suction in patients with high spinal injuries may precipitate life threatening bradycardia. The incidence of such bradycardia is reduced by preoxygenation before suction and the skilful use of the suction catheter. If appreciable bradycardia develops intravenous atropine should be given. Patients prone to serious bradycardias may be treated with an oral adrenal agonist such as orciprenaline before the flight.

We believe that if these recommendations are adopted patients with high spinal injury may be transported by air more safely.

1 McMichan JC, Michel L, Westbrook P. Pulmonary dysfunction following traumatic quadriplegia. FAMA 1980;243:528-31.

Siebens AA. Kirbv NA. Poulos DA. Cough following transection of spinal cord at $\mathrm{C6}$. Arch Phys Med Rehabil 1964;45:1-8.

3 Preston FS, Denison DM. Aerospace medicine. In: Weatherall DJ, Ledingham JGG. Warrell DA, eds. Oxford textbook of medicine. 2nd ed. Oxford: Oxford Medical Publications, 1987:106-20.

4 Brownlee S. Williams SJ. Physiotherapy in the respiratory care of patients with high spinal injurv. Physiotherapy 1987;73:148-52.

5 Frankel HL. Marthias CJ, Spaldin JMK. Mechanisms of reflex cardiac arrest in tetraplegic patients. Lancet 1975; ii:1183-5.

Accepred 12 March 1990

\section{Plasma concentrations of tryptophan and dieting}

\author{
G M Goodwin, P J Cowen, C G Fairburn, \\ M Parry-Billings, P C Calder, E A Newsholme
}

Unit, Royal Edinburgh Hospital, Edinbargh EH10 SHF

G M Goodwin, MRCPSYCH, clinical scientist

\section{MRC Unit of Clinical Phannacolosy and University Department of Pychiotry, Litilemone Hospital, Oxford OX44XN PJ Cowen, MD, clinical scientist \\ C G Fairburn, MRCPSYCH, \\ Wellcome Trust senior lecturer \\ Departmeat of \\ Biochemistry, University of \\ Oxfond, Odford OX1 3QU \\ M Parry-Billings, DPHIL, \\ Medical Research Conncil research fellow \\ PCCalder, PHD, Nuffield \\ medical fellow \\ E A Newsholme, DSC, \\ lecturer}

\section{Correspondence to: Dr} Goodwin.

BrMed J 1990;300:1499-500 how diets can be made easy, effective, and healthy. They often speculate on the relation between food intake and subjective experience, but this has generated only one important scientific hypothesis in the past 20 years. ${ }^{1}$ None of the brain enzymes that convert plasma substrate. A fall in the plasma concentration of tryptophan should therefore reduce the rate of synthesis and hence the serotonin concentration. Serotonin is believed to be important in regulating appetite, sexual activity, and the control of impulses, and strong circumstantial evidence links abnormalities in serotonin concentration with depression. Indeed, total exclusion of tryptophan from the diet produces depression. No systematic study has been made of changes in the plasma concentrations of key amino acids in mildly overweight subjects taking low energy diets to lose weight.

\section{Subjects, methods, and results}

Eight men and eight women with a body mass index within the normal range for Western societies (men $21-30 \mathrm{~kg} / \mathrm{m}^{2}$; women $21-27 \mathrm{~kg} / \mathrm{m}^{2}$ ) were recruited to take a weight reducing diet of 4-18-5-02 $\mathrm{MJ} /$ day. The
Dieting to lose weight is commonplace in Western societies. Numerous popular publications advise on tryptophan to serotonin approaches saturation with

Mean (SD) concentrations of energy metabolites and amino acids before and during diet

\begin{tabular}{|c|c|c|c|c|}
\hline & \multicolumn{2}{|c|}{ Men } & \multicolumn{2}{|c|}{ women } \\
\hline & Before & During & Before & During \\
\hline 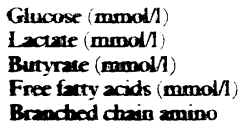 & $\begin{array}{l}4.4(0.6) \\
1.91(0-44) \\
0.33(0-28) \\
1.01(0.70)\end{array}$ & $\begin{array}{l}3.9(0-6) \\
1.61(0-22) \\
0-35(0-19) \\
0-76(0-47)\end{array}$ & $\begin{array}{l}3.7(0.8) \\
1.64(0.15) \\
0.33(0.20) \\
0.92(0-47)\end{array}$ & $\begin{array}{l}3.7(0-2) \\
1.68(0-30) \\
0.41(0-39) \\
0.96(0-30)\end{array}$ \\
\hline $\begin{array}{l}\operatorname{acids}(\mu \mathrm{mol} / /) \\
\text { Abrine }(\mu \mathrm{mol} / \mathrm{I}) \\
\text { Glutamine }(\mu \mathrm{mo} / \mathrm{I})\end{array}$ & $\begin{array}{l}405(61 \cdot 7) \\
339(53 \cdot 6) \\
373(57 \cdot 7)\end{array}$ & $\begin{array}{l}455(65 \cdot 9) \\
245(48.6) t \\
356(65 \cdot 1)\end{array}$ & $\begin{array}{l}344(65 \cdot 7) \\
261(59 \cdot 0) \\
373(58 \cdot 8)\end{array}$ & $\begin{array}{l}336(51 \cdot 6) \\
270(50 \cdot 7) \\
384(44 \cdot 9)\end{array}$ \\
\hline Tryprophan (umal/) & $57.5(12.0)$ & $45 \cdot 2(6 \cdot 4) t$ & $49.8(11.8)$ & $40 \cdot 6(4-8)^{\star}$ \\
\hline
\end{tabular}

${ }^{*} p<005 . \quad+p<0.02$. study was approved by the local ethics committee. Blood samples were taken after an overnight fast before the diet and during the third week of dieting. The women were studied in the middle of consecutive menstrual cycles and started dieting with the onset of the menses.

The diet was designed by the department of nutrition and dietetics, Oxford University. The subjects were given information about high and low energy foods and recommended a daily dietary allowance of 0.51 skimmed milk; $20 \mathrm{~g}$ polyunsaturated margarine; two servings of lean meat $(60 \mathrm{~g})$, white fish $(120 \mathrm{~g})$, cheese $(30 \mathrm{~g})$, cottage cheese $(90 \mathrm{~g})$, one egg, or one small carton of yoghourt; five slices of wholemeal bread; one serving of wholegrain breakfast cereal; and two portions of fruit.

Blood was collected in heparinised tubes and the plasma separated by centrifugation at $2000 \mathrm{rpm}$ and stored at $-30^{\circ} \mathrm{C}$. Assays of metabolites are described elsewhere. ${ }^{34}$ Results were compared with the paired $t$ test (two tailed).

All the subjects lost weight; the men lost a mean of $5.4 \mathrm{~kg}(95 \%$ confidence interval 4.7 to $6.1 \mathrm{~kg})$ and the women $2.9 \mathrm{~kg}(2.3$ to $3.6 \mathrm{~kg})$. Food diaries showed good compliance with dietary recommendations. Dieting had no effect on the plasma concentrations of glucose, lactate, 3-hydroxybutyrate, branched chain amino acids, glutamine, or free fatty acids (table). While dieting the men had decreased plasma concentrations of alanine and both the men and the women had lower tryptophan concentrations. The ratio of the mean plasma concentrations of tryptophan to branched chain amino acids was also reduced (0.15 (SD 0.04) before $v 0.11(0.02)$ during the diet; $\mathbf{p}<0.02)$.

\section{Comment}

The weight reducing diet decreased the plasma concentrations of tryptophan in both the men and the women. The effect was greater in the men, but this may be explained by their greater reduction in energy intake to achieve $5.02 \mathrm{MJ} / \mathrm{day}$. The diet aimed at decreasing carbohydrate and fat intakes; protein intake was maintained and provided $800-1200 \mathrm{mg}$ tryptophan each day, which is considerably greater than either the minimum recommended amount $(250 \mathrm{mg})$ or the "safe" amount $(500 \mathrm{mg})$. Conventional dieting is thus likely to reduce tryptophan concentrations and hence the rate of synthesis of serotonin in the brain. 
The psychological consequences of diets that restrict energy intake are disputed. Our observations suggest that irritability and waking early in the morning were common in the third week of the diet. Whether these behavioural changes were related to decreased plasma concentrations of tryptophan could be investigated by supplementing the diet with tryptophan. There would be considerable interest if supplementation improved the compliance with, and effectiveness of, dieting Unfortunately, pharmaceutical preparations of tryptophan have been withdrawn because of their suspected association with the eosinophilia-myalgia syndrome. 'It may be feasible, however, to investigate the effect of supplementation with tryptophan by manipulating the dietary intake of tryptophan and other amino acids. Tryptophan remains important to the understanding of the relation between food intake and brain function.

We thank Norma Brearley for preparing the manescript.

I Wurtman RJ. Bebavioural effects of nutrients. Luncet 1983:1: [1+5-7.

2 Young SN, Smith SE, Pihl RO. Tryptuptan depletion causes a rapid luwering of mout in normol maks. Psychuphormorulugy $1985.87: 175$

3 Blomstrand E, Celsing F, Newsbuime EA. Changes in plasma concentratives of aromaric and branched chain amino acids during sustesined exercise in min and their possible role in fatigue. Acta Phuswl Scundi 1988;133:115-21.

4 Ardawi MSM. Some aspects of energy metabolism in Ivmphocvtes. Oxtord: University of Oxford, 1983. pp 340. (DPhil thesis.

5 Comminter on Safery of Medticines. L-tryprophan and eosinuphilia-mvatejia syndrome in the USA. Current Problems 1989:27 (item I

(Accepced 6 February 1990

\title{
Impaired fibrinolytic capacity and early recurrent spontaneous abortion
}

\author{
J C Gris, J F Schved, S Neveu, P Mares, \\ $P$ Aguilar-Martinez, D Dupaigne
}

Departunent of

Haematology and

Immunology, University

Hospital, 30006 Nimes,

France

J C Gris, MD, consultant

I F Schved, MD, head of

departmeni

S Neveu, MD, consultant

P Mares, MD, consolitant

P Aguilar-Martinez, MD, consultont

D Dupaigne, $\mathrm{MD}$, comsultan

Correspondence and requests for reprints to: Dr J

C Gris, Laboratoire

d'Hématologie et

Immunologie, Centre

Hospitalier Régional et

Universitaire Gaston

Doumergue, 5 Rue Hoche

BP 26, 300006 Nîmes Cedex,

France.

Br.Medf 1990;300.1500
Impaired fibrinolytic activity in blood has been claimed to contribute to the development of deep venous thrombosis.' Placental infarction is often found in abortions associated with lupus-like anticoagulants.' We report the fibrinolytic capacity in the plasma of women suffering from recurrent spontaneous abortions.

\section{Patients, methods, and results}

We studied 20 women aged 22-41 (mean 34 ) years with at least three episodes of spontaneous abortion occurring before the eighth week after the last men strual period. Results of hysterography and hormonal evaluation were normal in all cases. Each couple was assessed to have normal karyotypes. Women were negative for antispermatozoa, antinuclear, and antideoxyribonucleic acid antibodies and had developed antibodies to their partner's human leucocyte antigens. The absence of lupus-like anticoagulant was assessed by normal values of kaolin clotting time, activated partial thromboplastin time, tissue thromboplastin inhibition, and platelet neutralisation. Results of an enzyme linked immunosorbent assay (ELISA) for antiphospholipid and anticardiolipin antibodies were negative.

Fibrinolytic capacity was studied by using a 10 minute venous occlusion test between 9 and 11 am in non-pregnant women at least three months after the last abortion. A control group of 32 apparently healthy women aged 20-39 (mean 32) years was studied

Mean (SD) /rangel euglobulin clot bysis rime and immmonoassayable tissme oppe plasminogen actroator ouriations after venous acchusion (delsa \%), and values of plasminogen actroator inhibitor activity before venons acchusion in the control group and in 20 women with early spontaneous recurrent abortion

\begin{tabular}{lccc}
\hline & $\begin{array}{c}\text { Eughobulin clot lysis time } \\
(0 \%)\end{array}$ & $\begin{array}{c}\text { Tissue plasminogen activator } \\
(0 \%)\end{array}$ & $\begin{array}{c}\text { Plasminogen activator } \\
\text { inhibitor activity } \\
(\mathrm{U} / \mathrm{ml})\end{array}$ \\
\hline $\begin{array}{l}\text { Controls } \\
\text { Patients }\end{array}$ & $\begin{array}{l}-47(8)[-70 \text { to }-30] \\
-25(28)[-73 \text { to } 0]\end{array}$ & $\begin{array}{l}+85(22)[+40 \text { to }+135] \\
+62(49)[0 \text { to }+169]\end{array}$ & $\begin{array}{r}5 \cdot 5(5-0)[0 \text { to } 16-5] \\
10-6(8-3)[3 \text { to } 28 \cdot 2]\end{array}$ \\
\hline p Value* & $<0-01$ & $<0-02$ & $<0-01$ \\
\hline
\end{tabular}

U test. simultaneously. Plasma euglobulin fibrinolytic activity was measured by the euglobulin clot lysis time, tissue type plasminogen activator related antigen by an ELISA, plasminogen activator inhibitor activity by the method of Eriksson et al. ${ }^{3}$ Postocclusion plasminogen activator values were corrected for the change in packed cell volume by using the correction factor $(100$ poststasis packed cell volume $) /(100$ prestasis packed cell volume). Variations in variables induced by venous stasis were assessed by using the "delta \%" ( 0 \%) criterion, defined as (poststasis assay value-prestasis assay value)/prestasis assay value.

The table shows that patients had significantly less shortening of the euglobulin clot lysis time and a smaller increase in tissue tvpe plasminogen activator activity after venous stasis, and significantly higher plasminogen activator inhibitor activity before venous stasis.

\section{Comment}

Hypofibrinolysis generally stems from either deficient release of tissue type plasminogen activator or raised plasma concentrations of plasminogen activator inhibitor masking the fibrinolytic response to venous occlusion.' We found evidence of these abnormalities in 13 of the 20 women investigated for recurrent abortions. Deficient activator release (eight patients) was not corrected by desmopressin infusion (0-4 $\mu \mathrm{g} / \mathrm{kg}$ ).

The relevance of these data is unclear. Hypofibrinolysis is frequently associated with thrombosis. Abortions occurred very early and pathological examination of the placenta could not be performed. Fibrinolysis is also involved in the enzymatic basis of trophoblast invasiveness. ${ }^{+}$Hypofibrinolysis in mothers might be acquired and might explain a defect of plasminogen activation in trophoblast cells. The reason behind this remains to be clarified.

Impaired fibrinolytic capacity seems to be a common feature in women with early recurrent spontaneous abortions of unknown origin.

I Nibson IM, Liunger H, Tengborn L. Two different mectanisms in patient with veowus thrumbusis and defective fibrinolvsis: low concentrativas of phasminogen activatur or increased concentrations of plasamogen activator inhibitor. Br. Med f 1985:200:1453-6.

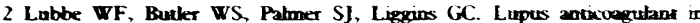
pregnancy. Bry Obstet Gymaecol 1984;91:357-63.

Eritsson E, Ranby M, Grzander E, Risberg B. Determination of ptasmmugen activator inhibitor in ptasma using t-PA and a chromugenic singte-point potyD-lusio stimututed assay. Thromb Res 1988;50-91-101

4 Strictband S, Reich E, Sberman MI. Plasminogen activator in eart embryogenesis: enzerme production by trophublast and parietal endoderm Cell 1976:9:231-10.

(Acceped 28 Febrown 1990 